\title{
Development of air quality forecasting system in Macedonia, based on WRF-Chem model
}

\author{
Vlado Spiridonov $^{1}$ (D) B Boro Jakimovski ${ }^{2}$ - Irena Spiridonova ${ }^{3} \cdot$ Gabriel Pereira $^{4,5}$
}

Received: 21 January 2019 / Accepted: 8 April 2019 / Published online: 2 May 2019

(C) The Author(s) 2019

\begin{abstract}
Urban air quality is composed of a complex interaction of factors associated with anthropogenic emissions, atmospheric circulation, and geographic factors; also, most of the urban pollution presents aerosols and trace gases toxic to human health and responsible for damaged flora, fauna, and materials. The air quality system based on the state-of-the-art Weather Research and Forecasting model coupled with chemistry (WRF-Chem) has been configured and designed for Macedonia. An extensive set of experiments have been performed with different model settings to forecast simultaneously the weather and air pollution over Macedonia. For the present work, a numerical simulation of extreme pollution episode over the urban area in Skopje has been simulated using 1-km WRFChem model and a newly developed set of urban mobile emissions. The modeled results implied that the model is very sensitive to the initial meteorological conditions, grid spacing, and mobile emissions. The results are validated against available observations for meteorological fields and pollutant concentrations. While the model forecasts with coarser horizontal grid resolution well fit with the hourly values of some air quality monitoring stations, these experiments tend to underpredict the peak level of about $1250 \mu \mathrm{g} / \mathrm{m}^{3}$ evidenced at the air quality station "Karpos." A WRF-Chem 5-km simulation shows increased PM $_{10}$ concentrations with a peak value of about $1325 \mu \mathrm{g} / \mathrm{m}^{3}$ a few hours before the evidenced extreme concentration while 2.5-km grid run indicates the initial accumulation of air pollution with relatively high concentration with peak $\mathrm{PM}_{10}$ on 5 February 2017 at 0100 UTC. The 1-km model configuration well captures the $\mathrm{PM}_{10}$ distribution over Skopje valley and the location and timing of the maximum measured air pollution. The verification analysis indicates that the best performance in the sense of the correlation coefficient is achieved with the 5-km WRF-Chem v.3.91 forecast. Numerical simulations with coarser grid resolution show less confidence and lower CC. The results suggest that model initialization and initial data using a mobile source emission provide a better quantitative assessment of extreme air pollution in urban areas. Overall, the present case study shows that the WRF-Chem model has an acceptable performance for meteorological variables as well as $\mathrm{PM}_{10}$ concentration over Skopje. This study provides a general overview of WRFChem simulations and can serve as a reference for future air quality modeling studies.
\end{abstract}

Keywords WRF-Chem $\cdot$ Air quality modeling $\cdot$ Extreme pollution episode $\cdot \mathrm{PM}_{10} \cdot$ Urban area

Electronic supplementary material The online version of this article (https://doi.org/10.1007/s11869-019-00698-5) contains supplementary material, which is available to authorized users.

Vlado Spiridonov

vlado.spiridonov@univie.ac.at

1 Department of Meteorology and Geophysics, Faculty of Earth Science, Geography and Astronomy, University of Vienna, 1090 Vienna, Austria

2 Faculty of Computer Science and Engineering, "Ss. Cyril and Methodius" University - Skopje, Skopje, Macedonia

3 Intertec - Product Development Company, Skopje, Macedonia

4 Department of Geoscience, Federal University of São João del Rei (UFSJ), São João del Rei, Brazil

5 Graduate Program in Physical Geography, University of São Paulo (USP), São Paulo, Brazil

\section{Introduction}

The urban air quality has become one of the main concerns of the local authorities of Macedonia cities due to the poor air quality, especially during the winter season, where the pollution is higher causing a negative impact on human health (Mindell and Joffe 2004). The problem associated with air pollution is very complex as many factors contribute to increases concentrations of the main pollutants (e.g., urbanization, specific topography, emissions sources, environmental factors, meteorology). The main pollutants emitted into the atmosphere in urban areas such as Skopje are sulfur oxides $\left(\mathrm{SO}_{2}\right)$, nitrogen oxides $\left(\mathrm{NO}_{\mathrm{x}}\right)$, carbon monoxide $(\mathrm{CO})$, and particulate matter (PM/aerosols), mostly consisting of black 
carbon, sulfates, nitrates, and organic matter. From these reasons, it is necessary to carry out advanced research based on observational, theoretical, and modeling studies in the evaluation and estimation of the impact of different emissions (anthropogenic, biogenic, and especially mobile emissions) on air pollutant concentrations in urban areas, since the urban sources of variety of gaseous and particulate matters have the largest contribution to anthropogenic emission (Seinfeld and Pandis 1998). These chemical pollutants include primary $\mathrm{PM}_{10}$ and $\mathrm{PM}_{2.5}$, which are directly emitted in the atmosphere from various sources (e.g., road traffic, construction sites, soil dust, fires, fuel consumption), and secondary PM, which is formed in the atmosphere via chemical reactions in gas and aqueous phases, leading to the oxidation of precursors such as sulfur dioxide $\left(\mathrm{SO}_{2}\right)$ and nitrogen oxides $\left(\mathrm{NO}_{\mathrm{x}}\right)$. The recent economic developments in Macedonia and the increasing urbanization will potentially cause wide-ranging consequences in terms of environmental and health problems in the urban areas (especially in the city of Skopje).

Real-time forecast of urban air quality is a relatively new discipline in atmospheric science and highly important to the public as advanced information for both air quality and safety assessment. The rapid computer development in the past years allowed the use of advanced offline deterministic 3-D chemical transport models (CTMs), leading to more accurate air quality forecast, replacing the previous empirical and statistical approach which has some limitations and misses to adequately represent the physical and chemical processes of pollutants. Nevertheless, these models are more expensive regarding the computation time they consume; they show significant advances as they are capable of simulating the complex physical-chemical processes (Zhang et al. 2012; Spiridonov et al. 2018).

Many of these were offline which implies that the CTM is running after the meteorological simulations such as EMEP (Simpson et al. 2012), SILAM (Sofiev 2000) (http://silam.fmi. fi, AERMOD) (Cimorelli et al. 2004), TM5 (Krol et al. 2005), CMAQ (Byun and Schere 2006; Matthias 2008), CHIMERE (Bessagnet et al. 2008; Menut et al. 2014), LOTOS-EUROS (Schaap et al. 2008), REMOTE (Langmann et al. 2008), and ENVIRON (2011). The online coupled models have been developed to better understand the physical-chemical processes of gas-phase species and particulate matter and are being applied in different parts of the world (e.g., MCCM, Grell et al. 2000; GATOR-GCMM, Jacobson 2001; Meso-NH-C, Tulet et al. 2003; WRF-Chem, Grell et al. 2005; EnviroHIRLAM, Baklanov et al. 2008; GEMAQ, Kaminski et al. 2008; WRF-Chem-MADRID; Zhang et al. 2010). A more detailed information regarding the strengths and constraints of offline or online CTMs could be found in the studies by Zhang (2008), Kukkonen et al. (2012), Grell and Baklanov (2011), or Baklanov et al. (2014).

Here, we propose the air quality forecast and alert system based on the WRF-Chem model with optimum settings (meteorology and chemistry) and determined through extensive testing, which best simulates both meteorological and air quality available measurements. In the present study, we have focused on the simulation of high $\mathrm{PM}_{10}$ episode that occurred at nighttime between 4 and 5 February 2017. The evaluation of modeled meteorological variables and $\mathrm{PM}_{10}$ concentration is based on the comparison with ground-based observations of various chemical species established by the Ministry of Environment and Physical Planning (MOEPP). There are many reasons for focusing on Skopje, such as rapid urbanization and population of the city, complex topography of the valley surrounded with the mountains where frequently, under stable atmospheric conditions, winter fog and smog are commonly found with increased pollution accumulation, and mobile traffic emissions which significantly increase the levels of air pollutant concentrations well above the national ambient air quality standard, especially for $\mathrm{PM}_{10}$ particulate matters. The other reason arises from the fact that this is the first attempt in developing of the air quality system based on WRFChem model to simulate the urban air pollution across the country of Macedonia and its major city, Skopje.

\section{Design of the system}

The organizational structure of the prototype of this system depicted in Supplemental Material Fig. S1 includes four components: meteorology, chemistry, emissions, and advanced air quality visualization tool. The system is designed for regionaland urban-scale air quality forecast. It incorporates the Weather Research Forecast non-hydrostatic mesoscale model, coupled with the chemistry model, emission data set, and the air quality information module.

\section{WRF meteorological model}

The meteorological module is based on the Advanced Research WRF (ARW) core developed by the NCAR (Skamarock et al. 2008). The ARW is a non-hydrostatic mesoscale model with a compressible equation on C-grid staggering, using a terrain-following hydrostatic pressure-vertical coordinate. It conserves mass, momentum, dry entropy, and scalars using a flux-conserving form for all prognostic equations. The numerical methods utilize third-order Runge-Kutta split-explicit time differencing, together with higher-order advection. The ARW supports a two-way interacting moving nested grids and offers numerous physical packages. The model uses WSM6 microphysics developed by Hong and Lim (2006). The planetary boundary layer (PBL) parameterization scheme is based on Yonsei University (YSU) (Hong et al. 2006). The land surface model (LSM) is according to Chen and Dudhia (2001). The atmospheric shortwave and longwave radiations were computed according to the scheme 
proposed by Dudhia (1989) and by the Rapid Radiative Transfer Model (RRTM) scheme (Mlawer et al. 1997), respectively. More about the technical details of the ARW system could be found in Skamarock et al. (2005).

\section{WRF-Chem model}

The Weather Research and Forecasting model ARW is coupled with chemistry (WRF-Chem), as an efficient and flexible system for weather and air quality forecast in Macedonia. WRF-Chem was developed at the NOAA/ESRL (National Oceanic and Atmospheric Administration/Earth System Research Laboratory). Detailed descriptions of the model were given in Grell et al. (2005). Fast et al. (2006) updated WRF-Chem by incorporating complex gas-phase chemistry, aerosol treatments, and photolysis scheme. The air quality component of WRF-Chem is fully consistent with the meteorological component; both components use the same transport scheme (mass and scalar preserving), the same horizontal and vertical grids, the same physical schemes for subgrid-scale transport, and the same time step for transport and vertical mixing.

In our system, we have employed the last WRF-Chem v.4.0 released at the NCEP in June 2018 as a basis for the chemical transport forecast. The Regional Acid Deposition Model version 2 (RADM2) chemical mechanism for gasphase chemistry schemes (Stockwell et al. 1990) is without kinetic pre-processor (KPP). In addition, the present air quality modeling system includes also the Modal Aerosol Dynamics Model for Europe (MADE), as aerosol mechanism proposed by Ackermann et al. (1998), coupled with the SORGAM (Secondary Organic Aerosol Model) parameterization (Schell et al. 2001) for $\mathrm{PM}_{10}$ simulations.

\section{Emissions data setup}

The urban air quality was derived from daily inventories built in the emission pre-processor-denominated PREP-CHEMSRC. The PREP-CHEM-SRC is a tool developed to estimate the emission fields of aerosols and trace gases from biomass burning (by satellite observations and inventories), biogenic, urban-industrial, biofuel use, and volcanic and agricultural waste burning sources for regional and global transport models based on available inventories and products (Freitas et al. 2017). The main objective of PREP-CHEM-SRC is to estimate the emission fields of the main trace gases and aerosols for use in atmospheric-chemistry transport models, such as WRF-CHEM.

In this work, we used the global anthropogenic emission data for gaseous species $\left(\mathrm{CO}_{2}, \mathrm{CO}, \mathrm{NO}_{\mathrm{x}}=\mathrm{NO}+\mathrm{NO}_{2}, \mathrm{SO}_{2}\right.$, $\mathrm{NH}_{3}$ ) compiled and distributed by the Emission Database for Global Atmospheric Research (EDGAR) system (http://www. mnp.nl/edgar) (Olivier et al. 2005). The EDGAR-HTAP project compiled a global emission data set with annual inventories for $\mathrm{CH}_{4}, \mathrm{NMVOC}, \mathrm{CO}, \mathrm{SO}_{2}, \mathrm{NO}_{\mathrm{x}}, \mathrm{NH}_{3}, \mathrm{PM}_{10}, \mathrm{PM}_{2.5}$, $\mathrm{BC}$, and $\mathrm{OC}$ and covering the period $2000-2005$ for $10 \mathrm{ag}-$ gregated sectors and on a global $0.1^{\circ} \times 0.1^{\circ}$ resolution. The global emission data comes from the Reanalysis of the Tropospheric (RETRO) (http://retro.enes.org) $(0.50 \times 0.50)$ monthly 1960-2000 emission base and GOCART background emission data. The model uses anthropogenic emissions from a number of global and regional inventories, biomass burning emissions from the Global Fire Emission Database, and biogenic emissions from Model of Emissions of Gases and Aerosols from Nature (MEGAN). The detailed description of the different emission datasets, model configuration, and processes are described by Emmons et al. (2010). This data set is inserted in PREP-CHEM-SRC to estimate the emission fields over the user-specified simulation domain. The novelty in the emission data setup is the development of the mobile emission inventory in the urban areas in Macedonia with special emphasis on Skopje city (the most populated), as described above.

\section{Urban mobile emissions}

The novelty in the emission data setup is the development of the method for the representation of the mobile emission inventory in the urban areas in Macedonia, with special emphasis on Skopje city as the most populated. The mobile emission implemented in the system represents an emission inventory updated by the Ministry of Environmental and Physical Planning (MOEPP). The data emissions distributed by the GNFR sectors with a grid resolution of $0.1^{\circ} \times 0.1^{\circ}$ lat/long are part of the Central Data Repository of European Environment Information (EIONET) and Observing Network of Long-Range Transport and Pollution Convention (CLRTAP). The inventory data set represents emissions in kt (kilotons) per year for each grid cell by chemical species (including $\mathrm{CO}$ and $\mathrm{NO}_{\mathrm{x}}$ ). The emission rates and the coordinates are positioned in the central point of each given grid. Two approaches of the creation of mobile emission data were used. The first set of emissions uses the gridded mobile inventory data provided by the MOEPP with a resolution of $0.1^{\circ} \times 0.1^{\circ}$ lat/long with a surface area of about $11.10 \mathrm{~km} \times 8.539 \mathrm{~km}$ or $94.78 \mathrm{~km}^{2}$ approximately which corresponds at $40^{\circ}$ latitude. The domain-averaged emission rates of $\mathrm{CO}$ and $\mathrm{NO}_{\mathrm{x}}$ for the central point of each grid box are then calculated by the given emission rates from the four adjacent points, using a bilinear interpolation method.

The second one is developed for this study by creating polygons of the major municipalities in Macedonia with definition of exact boundaries and the total rural and urban surface area $\mathrm{km}^{2}$ and estimation of the corresponding mobile emissions rates of $\mathrm{CO}$ and $\mathrm{NO}_{\mathrm{x}}$ averaged over the selected urban area. 


\section{The configuration of the system}

The system employed four single model configurations defined on a Lambert projection. The basic numerical integration is performed with $5-\mathrm{km}$ horizontal grid resolution centered at $41.55^{\circ}$ N, $21.45^{\circ}$ E (see Fig. 1a) and covers Macedonia, with parts of Serbia, Bulgaria, Albania, and Greece. The grid network contains $70 \times 70$ grid points in both the east-west and north-south directions. The vertical grid in the model is composed of 35 levels from the surface to about $30 \mathrm{~km}$ with 10 levels within $1 \mathrm{~km}$ above the model surface. The three other configurations are specified for sub-regions as the urban area of Skopje agglomeration (D2) with a very fine-grid spacing of $1 \mathrm{~km}$ and the reference lat/long coordinates of the municipality "center" (see Fig. 1b). Other two domains cover the western agglomeration (D3) and eastern zone and with a grid resolution of $2.5 \mathrm{~km}$. Model integration domains are chosen to match the main agglomeration zones in Macedonia where air quality monitoring is performed (see Supplemental Material Fig. S2). The system also allows three two-way nested domains with spatial resolution changing from $9 \mathrm{~km}, 3 \mathrm{~km}$, to $1 \mathrm{~km}$. The WRF-Chem version 4.0 model was built over a mother domain (D1) with a $5-\mathrm{km}$ spatial resolution, 35 columns and 35 rows, centered at $41.99^{\circ} \mathrm{N}, 24.34^{\circ} \mathrm{E}$. It covers Macedonia, parts of Serbia, Bulgaria, Albania, and Greece. The first nested domain (D2) has a 3-km spatial resolution and comprises the whole Macedonia. The innermost domain (D3) is centered over Skopje valley, which includes all municipalities of Skopje city, with $1-\mathrm{km} \times 1-\mathrm{km}$ grid cells. The vertical structure of the model includes 35 layers covering the whole troposphere. Topography, land use, and land water datasets were interpolated from US Geological Survey (USGS) with the appropriate spatial resolution of each domain $\left(10^{\prime}, 2^{\prime}\right.$, and $30^{\prime \prime}$ for $\mathrm{D} 1, \mathrm{D} 2$, and D3, respectively). The model is initialized by the real boundary conditions using NCAR-NCEP's final analysis (FNL) data (NCEP-DSSI, 2005) having a spatial resolution of $0.25^{\circ} \times 0.25^{\circ}(\sim 27.7 \mathrm{~km} \times 27.7 \mathrm{~km})$ and a 6-h temporal resolution or NCEP GFS data with the same spatial resolution. There is also a possibility to use ECMWF initial meteorological fields and boundary conditions for the selected model domains. The maximum forecast duration with 5 - and $2.5-\mathrm{km}$ (Fig. 2) WRFChem runs is $120 \mathrm{~h}$, while for the $1-\mathrm{km}$ forecast of Skopje city, the urban air quality forecast is $48 \mathrm{~h}$ in advance (Figs. 2 and 3 ).

\section{Results}

The air quality modeling system has been extensively tested on different weather cases related to air pollution, using various configurations and model initializations. However, in order to avoid any overloading of our work due to the large volume of data, we only present the results of the specific case related to the extreme urban air pollution episode that occurred in Skopje on 4 February 2017.

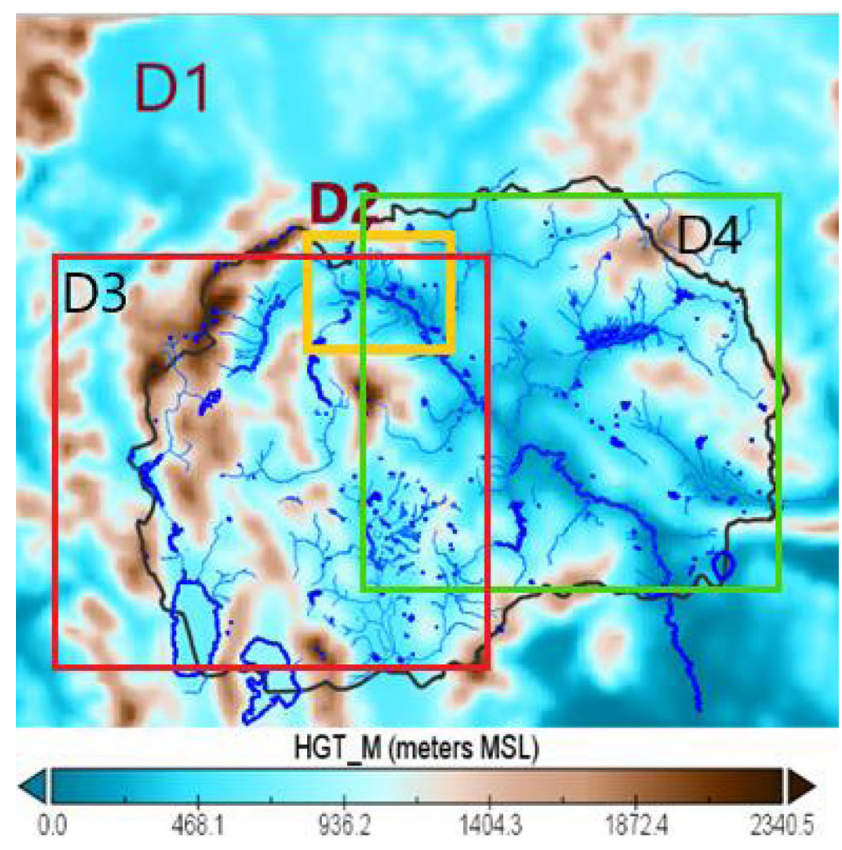

(a)

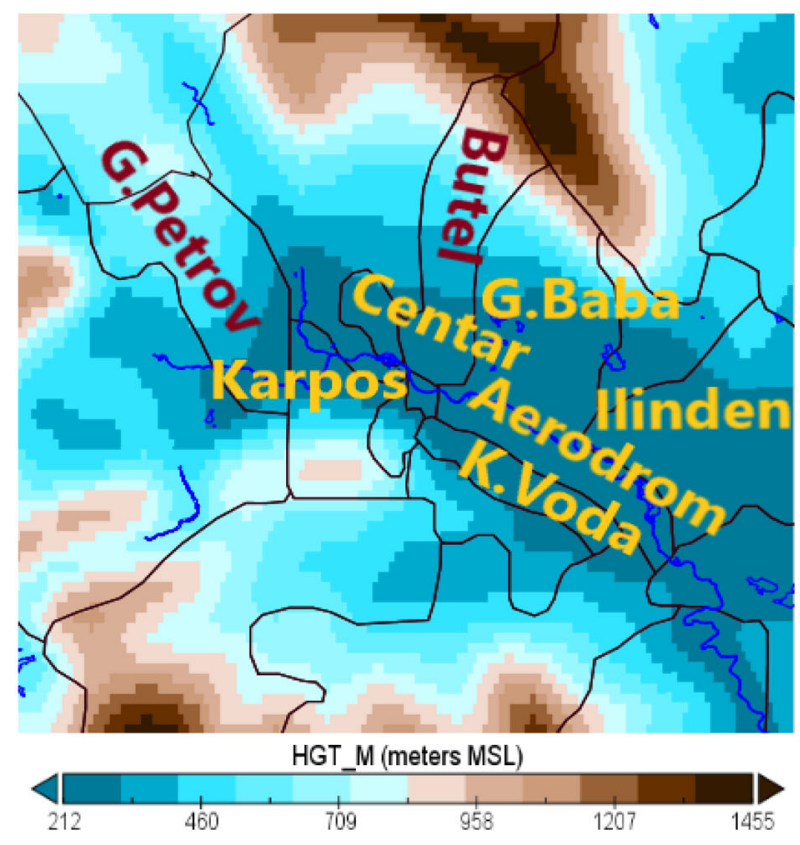

(b)

Fig. 1 Configuration of the WRF-Chem model domains. a Larger domain. b Skopje agglomeration

\section{Observational and forecast dataset}

Atmospheric systems play a crucial role in determining the status of the atmosphere, stability, and meteorological conditions. They act as a primary driving force and influence the 
PM10 Forecast Valid: 4 Feb 172300 UTC

WRF-Chem v. $4.0(7.5 \mathrm{~km}$ hor. resolution)

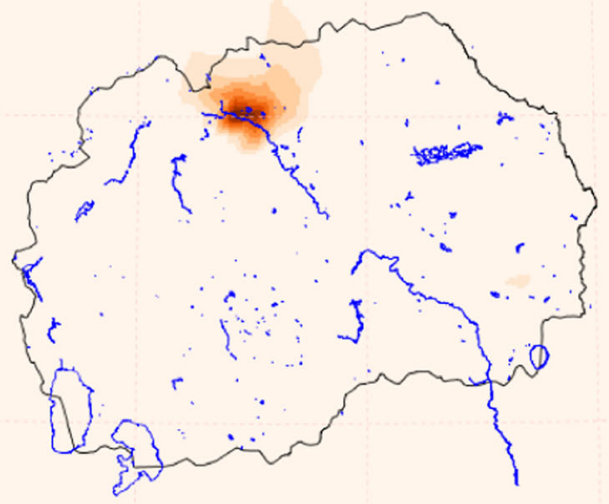

PM10 Forecast Valid: 4 Feb 172300 UTC

WRF_Chem v. 4.0 (2.5 km hor.resolution)

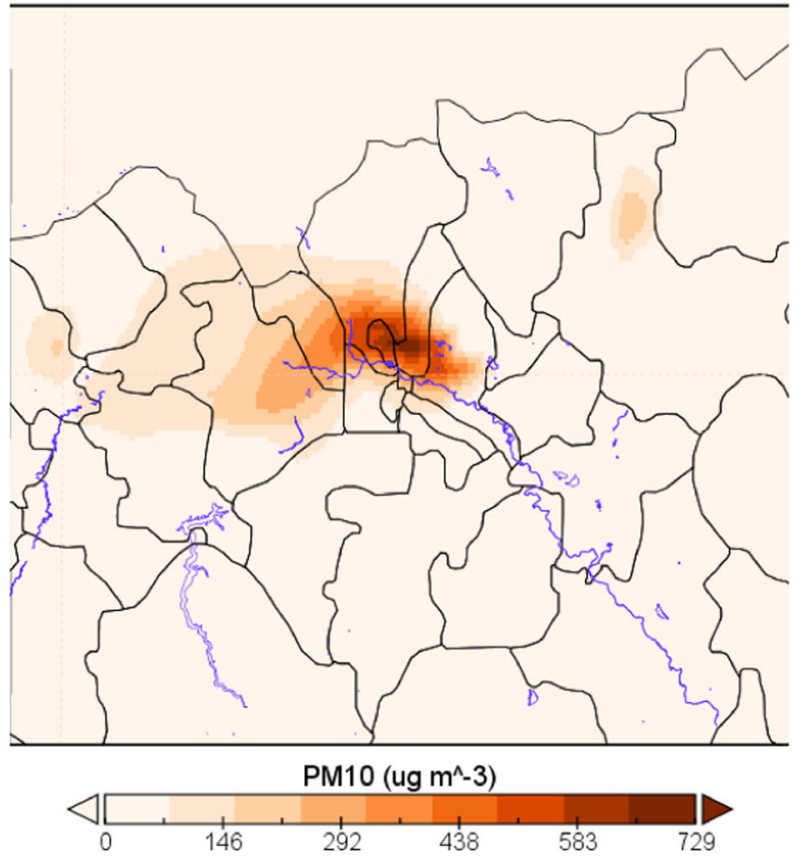

PM10 Forecast Valid: 4 Feb 172300 UTC

WRF-Chem v. 4.0 (5.0 km hor. resolution)
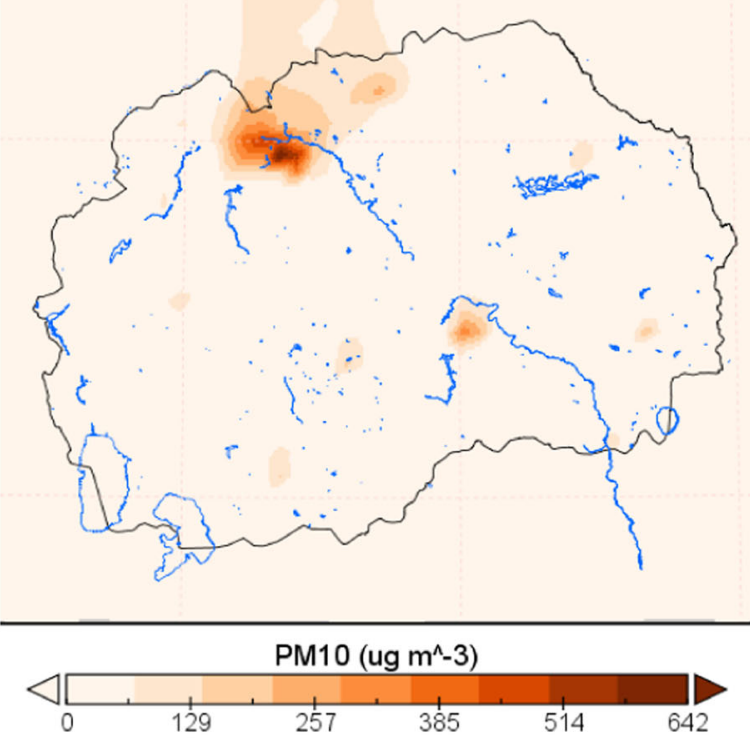

PM10 Forecast Valid: 4 Feb 172300 UTC WRF-Chem v. 4.0 (1.0 km hor. resolution)

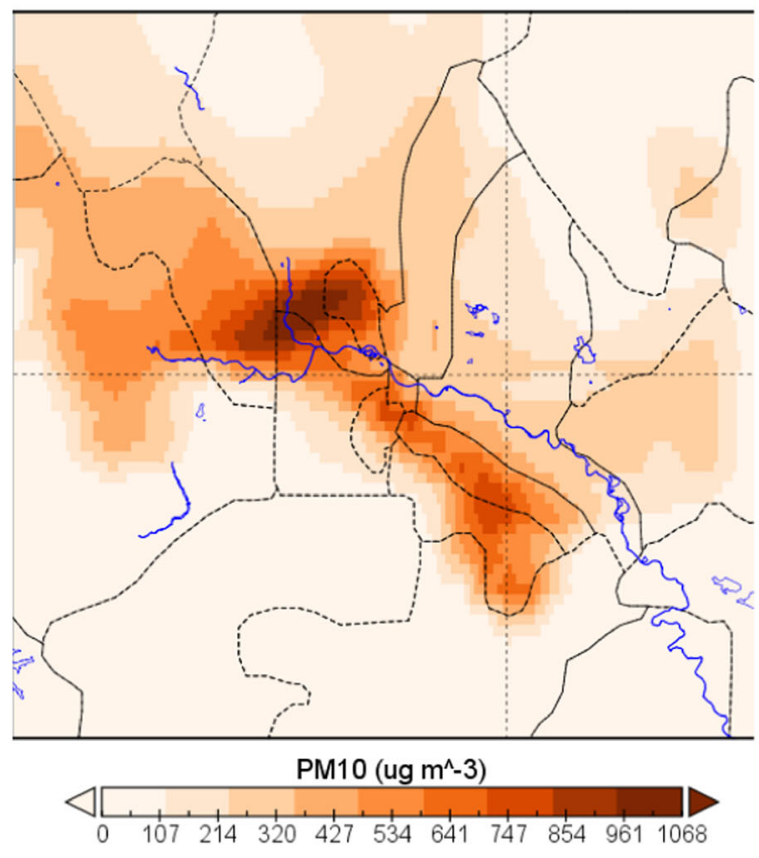

Fig. 2 Spatial distribution of WRF-Chem model (RADM2 scheme) of $\mathrm{PM}_{10}$ forecast with 7.5-, 5.0-, 2.5-, and 1.0-km grid resolution spatial distributions of $\mathrm{PM}_{10}$ with three separate peaks and more accurate quantitative assessment

dispersion of air pollution. As it is shown on Supplemental Material Fig. S3, the synoptic situation on 4 February 2017 was associated to high-pressure ridge at 500-hPa transit across South-eastern Europe, accompanied by warm advection at
$850 \mathrm{hPa}$ above valleys, the stable atmospheric conditions, a non-gradient surface pressure field, and stagnant air with a very weak wind flow, favoring the formation of persistent pools of cold air in Skopje Valley (see Supplemental 

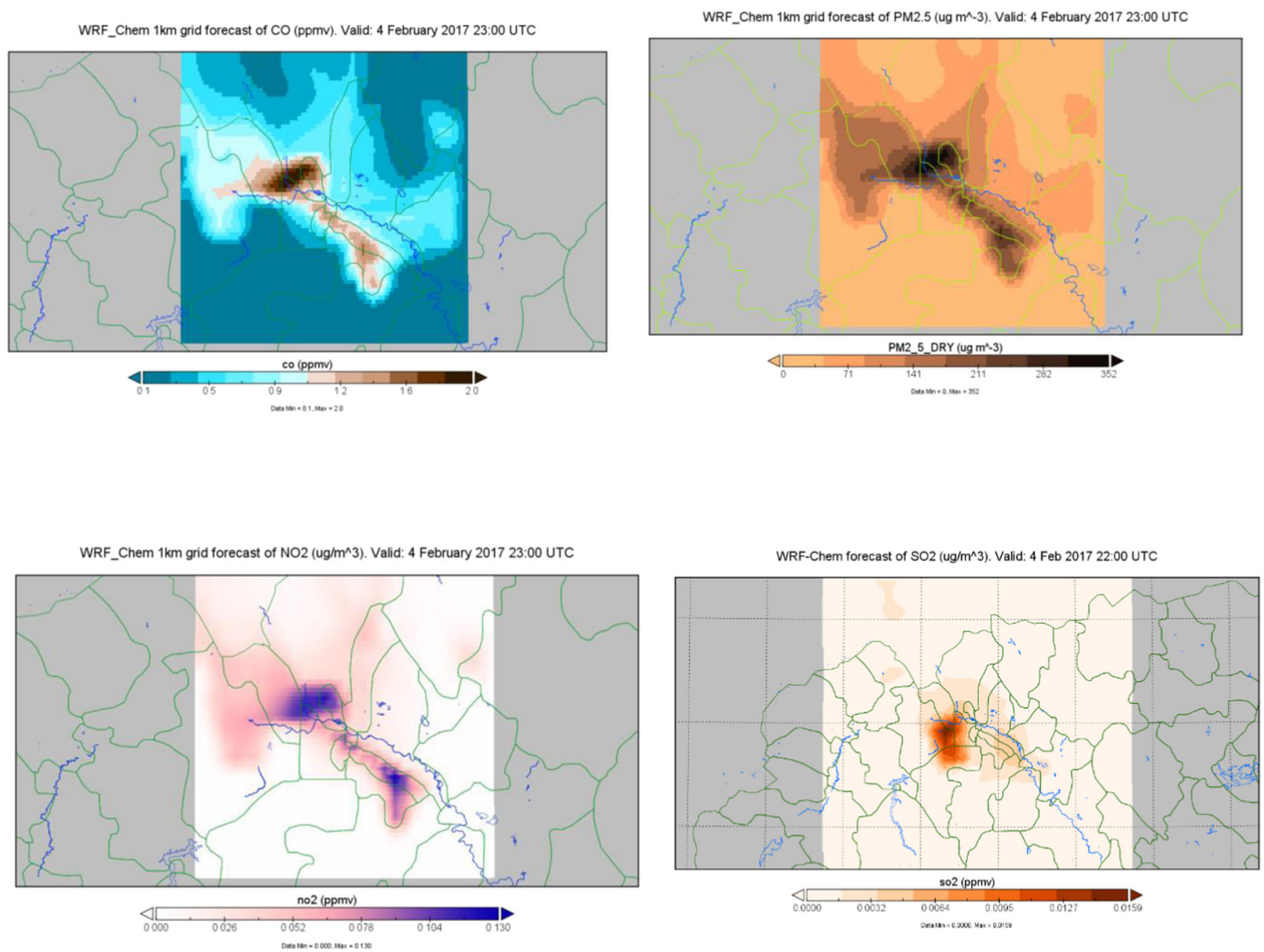

Fig. 3 The spatial distributions of $\mathrm{CO}, \mathrm{PM}_{2.5}, \mathrm{NO}_{2}$, and $\mathrm{SO}_{2}$ concentrations on 4 February 20172300 UTC obtained with 1-km WRF-Chem forecast

Material Fig. S4). Therefore, the existence of a very stable nocturnal condition over steep topography, under such meteorological conditions, results in air pollution accumulation and the maxima concentrations at some locations in Skopje. The persistence of high atmospheric pressure for a few days, with stable and stagnant atmospheric conditions with large moisture and weak (calm) wind, was favorable for pollution accumulation and increased concentrations in the Skopje valley. The specific topography of the Skopje valley surrounding with mountains also stimulated the process of accumulation of homogeneous air pollution inside the valley, causing extreme air pollution episode as the highest $\mathrm{PM}_{10}$ concentrations in Europe. For the night between the fourth and fifth of February 2017 in the Karpoš municipality, pollution levels were recorded high and were 24 times higher than the permitted level, i.e., the level of $\mathrm{PM}_{10}$ particles was $1218 \mu \mathrm{g} / \mathrm{m}^{3}$. The particulate matter with a size smaller than $2.5 \mu \mathrm{m}\left(\mathrm{PM}_{2.5}\right)$ was $206 \mu \mathrm{g} / \mathrm{m}^{3}$ which is 10 times higher than the permitted levels. The situation with the pollution was also bad in other municipalities, and in the center, the level of $\mathrm{PM}_{10}$ particles was $421 \mu \mathrm{g} / \mathrm{m}^{3}$ and $\mathrm{PM}_{2.5}-356 \mu \mathrm{g} / \mathrm{m}^{3}$. The air particle with a size of less than $10 \mu \mathrm{m}$ in Lisiče was $667 \mu \mathrm{g} / \mathrm{m}^{3}$ and in Gazi Baba $618 \mu \mathrm{g} / \mathrm{m}^{3}$. As it is shown in Fig. 4, the synoptic situation on 4 February 2017 was associated with high-pressure ridge at 500-hPa transit across South-eastern Europe, accompanied by warm advection at $850 \mathrm{hPa}$ above the valleys, the stable atmospheric conditions, a non-gradient surface pressure field, and stagnant air with a very weak wind flow, favoring the formation of persistent pools of cold air in the Skopje valley (Fig. 5). The existence of a very stable nocturnal condition over steep topography, under such meteorological conditions, results in air pollution accumulation and the maxima concentrations at some locations in Skopje.

\section{Forecast of the extreme air pollution episode}

The simulation was conducted for a high particulate matter episode, from 04 February at 1200 UTC to 05 February 2017 at 1200 UTC. The first $6 \mathrm{~h}$ of forecast period is considered spin-up time, while the remaining hours are used for analysis. The selection of temporal domain for particulate episodes is based on a 24-h average $\mathrm{PM}_{10}$ concentration 
Fig. 4 WRF-Chem model forecast with a different horizontal grid resolution vs measured $\mathrm{PM}_{10}$ concentration in the Skopje agglomeration on 4 th and 5th of February 2017 at 1200 UTC

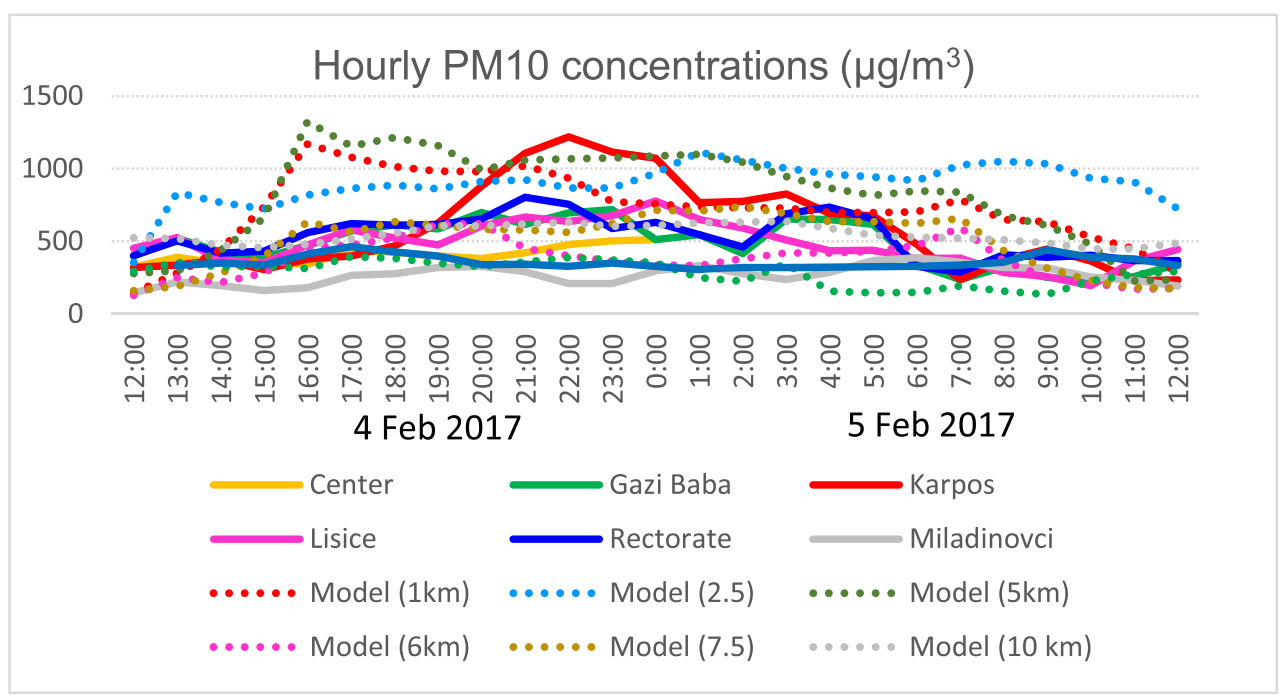

exceeding $50 \mu \mathrm{g} / \mathrm{m}^{3}$ at a minimum of two monitoring stations for at least two consecutive days across the study area. This approach allows for the evaluation of the chemical transport model under different atmospheric conditions, which are relevant for air quality.

Figure 2 shows the spatial distribution of 24-h average $\mathrm{PM}_{10}$ for RADM2 gas-phase chemistry scheme, over Macedonia using a different horizontal resolution. It is evident that WRFChem model is able to show the spatially distributed $\mathrm{PM}_{10}$ very well and that the WRF-Chem model with the RADM2 scheme shows a good performance in a 24 -h average $\mathrm{PM}_{10}$ concentration over the study domain. The simulations with a courser resolution tend to underpredict the $\mathrm{PM}_{10}$ concentration. A 2.5-km run indicates a slight increase of the 24-h average $\mathrm{PM}_{10}$ with similar pattern distribution as $5-\mathrm{km}$ run. WRFChem forecast employing $1-\mathrm{km}$ grid spacing shows a more realistic assessment of the 24-h averaged $\mathrm{PM}_{10}$. It is also seen that a peak concentrations are partially shifting from the time of the observations (not shown). It may be due to the biasness in the simulated wind direction by the model and the selected pattern of hourly emissions. The spatial patterns of $\mathrm{CO}$, $\mathrm{PM}_{2.5}$, and $\mathrm{NO}_{2}$ shown in Fig. 3 indicated that 1-km WRFChem configuration correctly captured the areas affected with high pollution, except for $\mathrm{SO}_{2}$ where the model overestimates the observed level. However, slight underestimation or overestimation may also be the result of the initial chemical input and model initialization or the complex urban meteorology in the Skopje valley. Therefore, the inclusion of data assimilation techniques may improve the overestimation or underestimation.

\section{The model sensitivity to different horizontal discretization}

A set of experiments have been performed using a different horizontal grid resolution of the model.
As seen from Fig. 4, the rapid increase of $\mathrm{PM}_{10}$ concentration at the station "Karpos" (red solid curve) started at about 1900 and lasted to 0100 on 5 February 2017 with a peak of $1260\left(\mu \mathrm{g} / \mathrm{m}^{3}\right)$, measured at around $2200 \mathrm{UTC}$. There are also high $\mathrm{PM}_{10}$ concentration measured at the "Rectorate" and also at the station "Lisice" located $10 \mathrm{~km}$ away. It is evident that 1-, $2.5-$, and 5-km runs show a relatively higher $\mathrm{PM}_{10}$ concentration compared with the observation and some coinciding in the rest of the simulation time. This overestimation occurs as the result of a fine resolution used and the time required for the model to redistribute the emissions in the model integration domain (spin time). The model runs with coarser resolution underestimating the maximum concentration, while reasonably fit with time evolution $\mathrm{PM}_{10}$ at the other stations. It implies that small-scale atmospheric processes in the atmospheric boundary layer (ABL), meteorological conditions, and the local features of the terrain play a significant role in pollution accumulation and therefore on the generation of poor ambient air quality. In the Supplemental Material Fig. S5, we have also displayed an hourly concentration of other pollutants for Skopje agglomeration versus modeled values. While the temporal evolution of $\mathrm{PM}_{2.5}$ particles and $\mathrm{NO}_{2}$ shows a certain similarity with the observed values, the model tends to underestimate $\mathrm{CO}$ and overestimate the value of the $\mathrm{SO}_{2}$, although the distribution of the $\mathrm{SO}_{2}$ fits well with the observed values at the rural station "Miladinovci." The general picture is that the WRF-Chem model has shown a good performance in forecasting the air pollution transport and redistribution processes in the urban areas. Certain differences are probably the result of the initial and boundary conditions of mobile emissions of pollutants, better representation of complex terrain that strongly affects the accumulation of pollutants, and the proper selection of PBL scheme that would best parameterize atmospheric processes in the terrestrial layer of the atmosphere. However, the initial results are really encouraging and with the further 
Fig. 5 Dispersion plots between observation (a) and forecast (b) of $\mathrm{CO}$ converted to $\mathrm{PM}_{2.5}$ and $\mathrm{PM}_{10}$, respectively

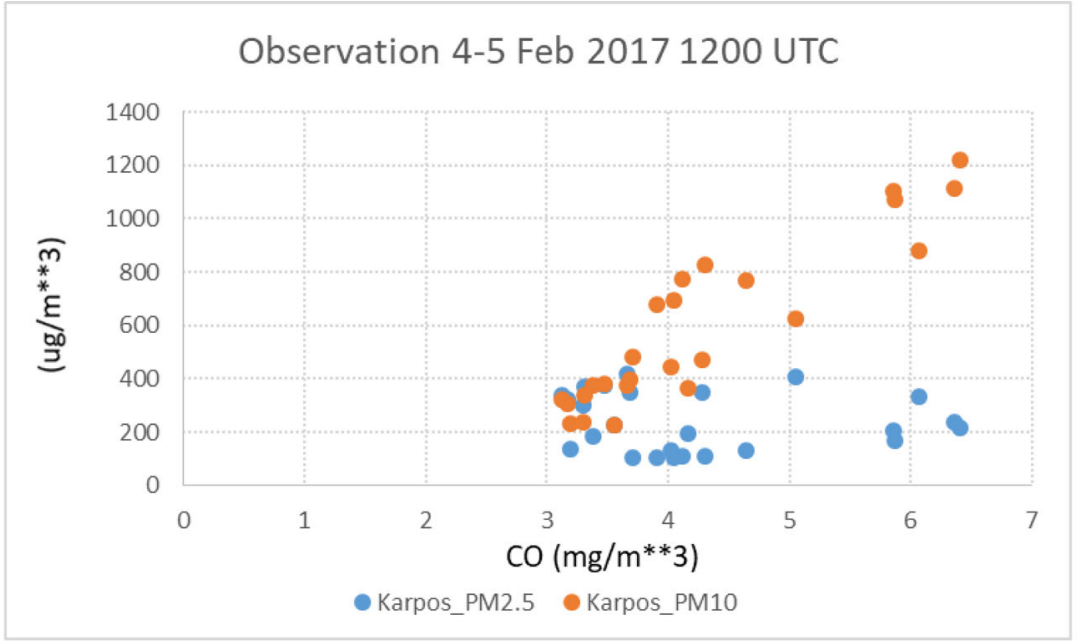

(a)

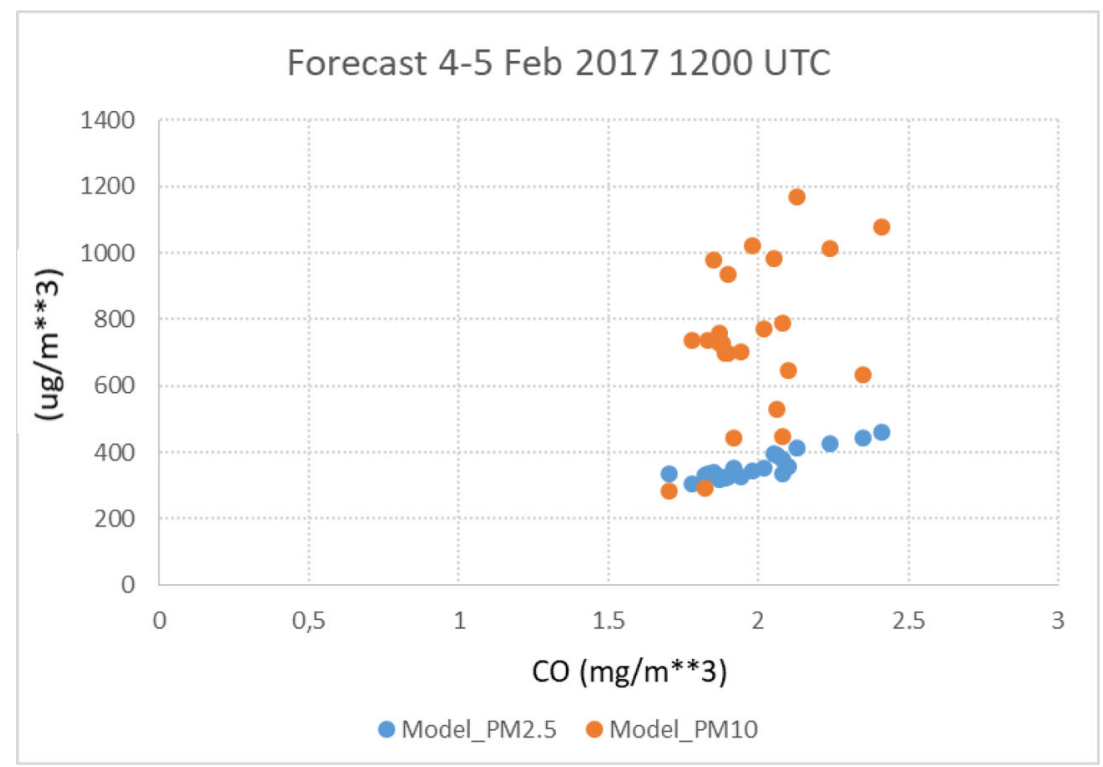

(b)

improvement of the abovementioned issues, it is not disputed that the urban air quality forecast system will further improve and adapt to best simulate atmospheric and chemical processes.

\section{The evaluation of the results with verification}

The evaluation of this study is carried out with the focus on the fine-grid domain (D3). There are seven air quality stations, namely Centar, Gazi Baba, Karpos, Lisice, Rektorat, Miladinovci, and the mobile station Butel which were selected to provide the surface air pollutant observations on an hourly basis over Skopje. The locations of these stations in Skopje agglomeration and in the whole country are depicted in Supplemental Fig. S3. Meteorological and chemical observational datasets from the aforementioned monitored stations are used for model evaluation.

The chemical species evaluated is the 24-h average $\mathrm{PM}_{10}$. The model is evaluated using a discrete evaluation. Bias error (BIAS), the mean absolute error (MAE), the root mean square error (RMSE), and the correlation coefficient (CC) are calculated against all available meteorological observations. We have evaluated WRF-Chem predictions for $\mathrm{PM}_{10}, \mathrm{PM}_{2.5}$, $\mathrm{CO}, \mathrm{NO}_{2}$, and $\mathrm{SO}_{2}$ as the most significant pollutants in terms of the urban air quality measurements. In this initial phase of developing the air quality forecast system in Macedonia, we only focused on system configuration, setup, and verification for the air quality forecast results with measurements. Our next task will be to develop an algorithm as a program interface for the assessment of the air quality and weather output 
data in order to define the appropriate health indices for the air pollution impact on health. Table 1 lists the statistical verification scores for domain-averaged $\mathrm{PM}_{10}$ concentration vs observation using the standard verification methods. The first set shows the domain-wide performance statistics for a 1-day forecast of 1.0-km WRF-Chem model of these pollutants vs observation. The results indicate a good model performance of a 1-km run (BIAS, MAE, RMSE, and CC of 5.64, 9.94, 17.94 $\left(\mu \mathrm{g} / \mathrm{m}^{3}\right)$, and 0.45 for an hourly value of $\mathrm{PM}_{10}$, respectively). The $\mathrm{CC}$ is also reasonably good for $\mathrm{SO}_{2}$ of 0.327 , with lower BIAS and RMSE. During the high pollution episode in the city of Skopje, $\mathrm{CO}$ and $\mathrm{PM}_{10}$ observations show a high correlation than $\mathrm{PM}_{2.5}$. This trend is also seen in the WRF-Chem $1-\mathrm{km}$ prediction of $\mathrm{CO}$ and $\mathrm{PM}_{10}$ but with a lower correlation of both $\mathrm{PM}_{10}$ and $\mathrm{PM}_{2.5}$ as the result of underprediction of $\mathrm{CO}$.

It is also interesting to note that a $5-\mathrm{km}$ run of WRF-Chem v.3.9.1 shows the best $C C$ of 0.59 , which is higher than the last released v. 4.0 using the same model configuration, initial meteorological and chemical fields, and boundary conditions. Obviously, with the increasing resolution, the correlation coefficient for $\mathrm{PM}_{10}$ is decreasing as seen from Table 1, because the local-scale atmospheric processes which have an influence on air pollution are not well represented (resolved) in a model with a coarser grid resolution. Another reason is that we used two sets of CO emissions in this study. The first one is the emission inventory provided by the MOEPP as gridded mobile source emissions data set with a resolution of $0.1^{\circ} \times 0.1^{\circ}$ lat/long which contributes about $90 \%$ of total $\mathrm{CO}$ emitted. The second set prepared in the present study is the same total annual amount of $\mathrm{CO}$ and $\mathrm{NO}_{\mathrm{x}}$ but with a different spatial distribution in created polygons of urban municipalities with exact boundaries. Therefore, by accurately predicting $\mathrm{CO}$, a good estimation of $\mathrm{PM}_{10}$ and $\mathrm{PM}_{2.5}$ 24-h mean can be made using a linear conversion with two proposed approaches suggested by Saide et al. (2012). The dispersion plots shown in Fig. 5 are in that direction implying that during nocturnal high pollution episode between 4 and 5 February 2017 in the Skopje valley, $\mathrm{CO}$ and $\mathrm{PM}_{10}$ hourly observations indicate a relatively good correlation that is also the case with forecast dispersion plots, where a quite good correlation is determined for $\mathrm{PM}_{10}$ particulate matters. However, these are only initial tests, and the results should be understood as preliminary. It is realistic to expect that the future experiments, with improved emissions, initial data, and model configurations, will show even better results.

\section{Advanced visualization tool}

Advanced graphical visualization tool has been developed as an integral component of a developed air quality forecast system. The novelty of the system is regarding the innovative

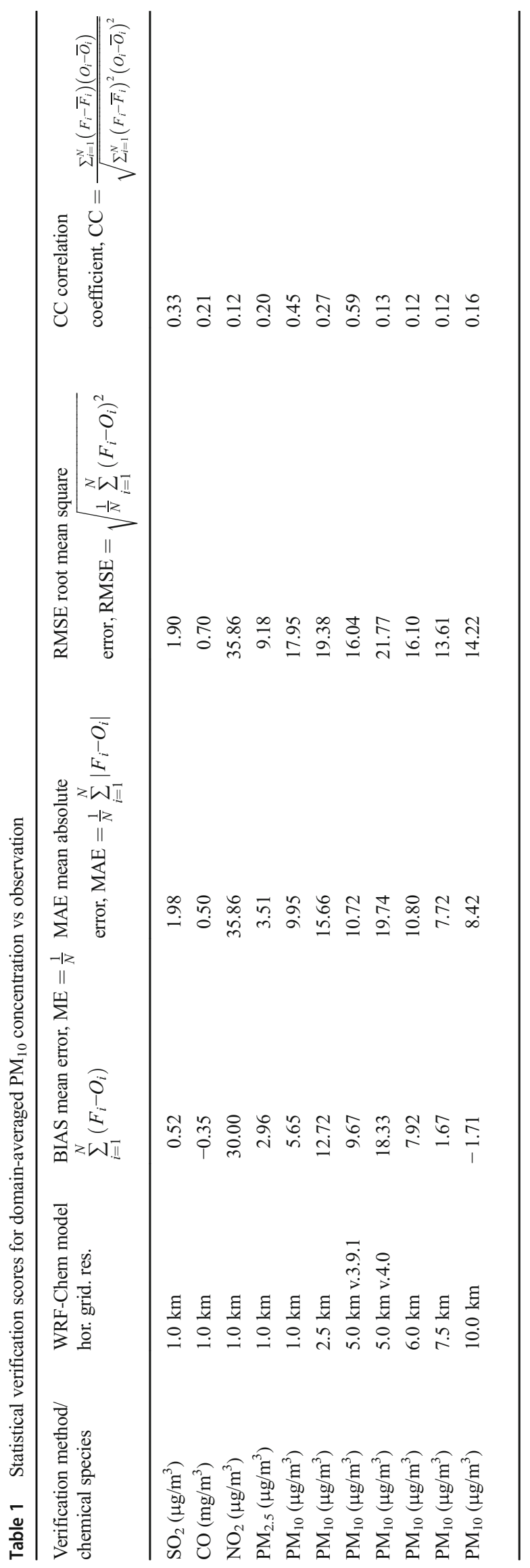


solutions of the contemporary approach and presentation of the modeled output weather and air quality data $\left(\mathrm{SO}_{2}, \mathrm{NO}_{\mathrm{X}}\right.$, $\mathrm{PM}_{10}, \mathrm{PM}_{2.5}, \mathrm{O}_{3}, \mathrm{CO}$, etc.) in Macedonia, a few days in advance. There are various available graphical software for reading the results obtained from the simulation. As such, we can mention Panoply netCDF, HDF and GRIB Data Viewer, NCO Tools, GrADS, and CDAT. Despite all these tools for reading the output data, of great importance for the present system is data extracting from the model and its dynamic display on a web page (without the need for a single file-by-file loading), processing, and chart preparation.

\section{Technologies and programming tools}

In the present system, we use the Spring Framework, an application framework for the Java platform along with Maven tool for building and managing Java-based projects, MySqlan open-source relational database management system, NetCDF_-Java 4.2.20 library, Angular-typescript-based open-source front-end web application framework, LeafletJavaScript open-source library for interactive maps, and the d3.js - JavaScript library for producing dynamic, interactive data visualizations in web browsers.

\section{Description of the technical solution}

The next steps that are listed below describe what is being implemented in this web-based application shown in the Supplemental Material Fig. S6, in order to automate the visualization process of the air quality forecast outputs for Macedonia as much as possible:

- Rename the output files of the model. Adding ncNetCDF extension;

- Creating a database of tables for the files, pollutants, and values;

- Enter the pollutant and file data tables;

- Loading the forecast files using the NetCDF_-Java 4.2.20 library with a variety of variables with different dimensions (e.g., $\mathrm{PM}_{10}, \mathrm{PM}_{2.5}$, RAINC, SNOW, XLAT, XLONG, $\left.\mathrm{SO}_{2}, \mathrm{~T}, \mathrm{NO}, \mathrm{NH} 3\right)$. For example, variables, such as RAINC - total accumulated precipitation, SNOWHphysical height of snow, XLAT-latitude, and XLONGlongitude, have three dimensions: time, west-east, and south-north. While variables such as $\mathrm{PM}_{10}, \mathrm{PM}_{2.5}$, and SO2 have four dimensions: time, west-east, south-north, and bottom top. For our case, we have considered only the surface level and therefore, we always take the bottom top to be equal to 1 . After we get the necessary values, we place them in the data table for the values given in the image above;
- Adjustment of output products of the model and their interpolation within the defined boundaries of individual municipalities;

- Developing of the design of the web application for an open access to all visualized data of the "Air quality forecast in the Republic of Macedonia," with many opportunities (e.g., selection of a date, time, and name of the variable) for the generation of an appropriate display. The example refers to a random date as given-October 1, 2018, at 10:00 AM UTC for $\mathrm{PM}_{10}$ particles. There is also another option "Municipality Map View," for the generation of a map with marked markers, which allows more detailed information about pollutant concentrations in some municipalities. The next is "Graphic View" option, for graphical visualization of the time evolution of any pollutant concentration.

The present system is under continuous development with the application of innovative solutions and sophisticated web design which will allow direct access, to understandable and valuable weather and air quality information.

\section{Conclusions}

A prototype air quality modeling system for Macedonia is developed based on the state-of-the-art coupled WRF-Chem model. It is designed for high-resolution weather and air pollution forecast over a regional domain which covers the whole country of Macedonia and three other selected domains which well fit the organization of the air quality measurements in Macedonia. A high-resolution version of the model with 1$\mathrm{km}$ grid spacing has been configured and applied to simulate the urban air quality over Skopje agglomeration during extreme $\mathrm{PM}_{10}$ concentration episode on 4 February 2017.

The model has been also tested for other case studies. The simulations were evaluated in terms of domain-wide discrete evaluation, as well as site-specific spatial and temporal evaluation. Sensitivity simulations were performed using RADM2 gas-phase chemistry scheme. A set of numerical runs implied that the model is very sensitive to the initial conditions and horizontal grid resolution. The results are validated against available observations for meteorological fields and pollutant concentrations. The meteorological variables (e.g., air temperature, relative humidity, and wind) indicate a small bias. While the $7.5-\mathrm{km}$ run shows a quite good agreement between modeled and observed hourly $\mathrm{PM}_{10}$ concentrations monitored at several stations, it tends to underpredict the extreme air pollution episode of about $1250 \mu \mathrm{g} / \mathrm{m}^{3}$ evidenced at the air quality station "Karpos." A WRF-CHEM 5-km simulation shows increase $\mathrm{PM}_{10}$ concentrations with a peak value of about $1325 \mu \mathrm{g} / \mathrm{m}^{3}$ a few hours before the evidenced extreme concentration while $2.5-\mathrm{km}$ grid run indicates the initial accumulation of air pollution with a relatively high concentration 
with peak $\mathrm{PM}_{10}$ on 5 February 2017 at 0100 UTC. The 1-km model configuration well captures the $\mathrm{PM}_{10}$ distribution over the Skopje valley and the location and timing of the maximum air pollution. The results suggest that model initialization and initial data using a mobile source emission provide a better quantitative assessment of extreme air pollution in the urban areas. The WRF-Chem model with the RADM2 scheme shows a good performance with respect to all statistical errors for $\mathrm{PM}_{10}$ concentration. Errors in simulating $\mathrm{PM}_{10}$ can be attributed to errors in simulating the $\mathrm{PM}_{10}$ components. Improving the simulations for $\mathrm{PM}_{10}$ species can help improve $\mathrm{PM}_{10}$ simulation overall. Bias in the simulations of $\mathrm{PM}_{10}$ species may compensate, leading to seemingly good $\mathrm{PM}_{10}$ simulations. The likely sources of errors in the forecasted $\mathrm{PM}_{10}$ components include uncertainties in both anthropogenic and biogenic emissions of PM precursors, which depend on meteorological predictions; uncertainties in emissions and chemistry over different locations (e.g., rural, urban, suburban); meteorological factors which can influence concentrations (e.g., T2, radiation for photochemistry, and PBL height); biases in cloud properties and precipitation which influence formation of PM components and their wet deposition; and the different properties of the sites from different sampling and measurement networks. Accurate emissions are also essential to improve air quality simulations. Continuous real-time emissions that feed into the models are ideal; however, this may not be feasible. Errors may arise in the estimates of anthropogenic and biogenic emissions, which should be minimized.

Acknowledgments Open access funding provided by University of Vienna. The authors wish to express their appreciation to the Ministry of Environmental and Physical Planning for the provision of air quality data from the online monitoring stations of Macedonia as well as for the additional air quality data provided by Ms. Martina Spasovska from the Macedonian Environmental Information Center. We also express our gratitude to the Faculty of Computer Science and Engineering FINKI for the allowance of using the high computer resources and performances for running and WRF-Chem model and processing.

Open Access This article is distributed under the terms of the Creative Commons Attribution 4.0 International License (http:// creativecommons.org/licenses/by/4.0/), which permits unrestricted use, distribution, and reproduction in any medium, provided you give appropriate credit to the original author(s) and the source, provide a link to the Creative Commons license, and indicate if changes were made.

\section{References}

Ackermann IJ, Hass H, Memmsheimer M, Ebel A, Binkowski FS, Shankar U (1998) Modal aerosol dynamics model for Europe: development and first applications. Atmos Environ 32:2981-2999

Baklanov A, Korsholm U, Mahura A, Petersen C, Gross A (2008) Enviro-HIRLAM: on-line coupled modelling of urban meteorology and air pollution. Adv Sci Res 2:41-46
Baklanov A, Schlünzen K, Suppan P, Baldasano J, Brunner D, Aksoyoglu S, Carmichael G, Douros J, Flemming J, Forkel R, Galmarini S, Gauss M, Grell G, Hirtl M, Joffre S, Jorba O, Kaas E, Kaasik M, Kallos G, Kong X, Korsholm U, Kurganskiy A, Kushta J, Lohmann U, Mahura A, Manders-Groot A, Maurizi A, Moussiopoulos N, Rao ST, Savage N, Seigneur C, Sokhi RS, Solazzo E, Solomos S, Sørensen B, Tsegas G, Vignati E, Vogel B, Zhang Y (2014) Online coupled regional meteorology chemistry models in Europe: current status and prospects. Atmos Chem Phys 14:317-398. https://doi.org/10.5194/acp-14-317-2014

Bessagnet B, Menut L, Curci G, Hodzic A, Guillaume B, Liousse C, Moukhtar S, Pun B, Seigneur C, Schulz M (2008) Regional modeling of carbonaceous aerosols over Europe-focus on secondary organic aerosols. J Atmos Chem 61:175-202

Byun DW, Schere KL (2006) Review of the governing equations, computational algorithms, and other components of the models -3 Community Multiscale Air Quality (CMAQ) modeling system. Appl Mech Rev 59:51-77

Chen E, Dudhia J (2001) Coupling an advanced land-surface/hydrology model with the Penn State/NCAR MM5 modeling system, Part 1: model description and implementation. Mon Weather Rev 129:569585

Cimorelli AJ, Perry SG, Venkatram A, Weil JC, Paine RJ, Wilson RB, Lee RF, Peters WD, Brode RW, Paumier JO (2004). AERMOD: description of ModelFormulation. EPA-454/R-03-004, USEPA, USA

Dudhia J (1989) Numerical study of convection observed during the Winter Monsoon Experiment using a mesoscale two-dimensional model. J Atmos Sci 46:3077-3107

Emmons LK, Walters S, Hess PG, Lamarque J-F, Pfister GG, Fillmore D, Granier C, Guenther A, Kinnison D, Laepple T, Orlando J, Tie X, Tyndall G, Wiedinmyer C, Baughcum SL, Kloster S (2010) Description and evaluation of the Model for Ozone and Related chemical Tracers, version 4 (MOZART-4). Geosci Model Dev 3: 43-67. https://doi.org/10.5194/gmd3-43-2010

ENVIRON (2011) CAMx User's Guide, Comprehensive Air Quality Model With Extensions Version 5.40, ENVIRON International Corporation, Novato, California

Fast JD, Gustafson WI Jr, Easter RC, Zaveri RA, Barnard JC, Chapman EG, Grell GA, Peckham SE (2006) Evolution of ozone, particulates, and aerosol direct radiative forcing in the vicinity of Houston using a fully coupled meteorology-chemistry-aerosol model. J Geophys Res 111:D21305

Freitas SR, Panetta J, Longo KM, Rodrigues LF, Moreira DS, Rosário NE, Silva Dias PL, Silva Dias MAF, Souza EP, Freitas ED, Longo M, Frassoni A, Fazenda AL, Santos e Silva CM, Pavani CAB, Eiras D, França DA, Massaru D, Silva FB, Santos FC, Pereira G, Camponogara G, Ferrada GA, Campos Velho HF, Menezes I, Freire JL, Alonso MF, Gácita MS, Zarzur M, Fonseca RM, Lima RS, Siqueira RA, Braz R, Tomita S, Oliveira V, Martins LD (2017) The Brazilian developments on the Regional Atmospheric Modeling System (BRAMS 5.2): an integrated environmental model tuned for tropical areas. Geosci Model Dev 10:189-222. https:// doi.org/10.5194/gmd-10-189-2017

Grell GA, Baklanov A (2011) Integrated modeling for forecasting weather and air quality: a call for fully coupled approaches. Atmos Environ 45:6845-6851

Grell GA, Emeis S, Stockwell WR, Schoenemeyer T, Forkel R, Michalakes J, Knoche R, Seidl W (2000) Application of a multiscale, coupled MM5/chemistry model to the complex terrain of the VOTALP valley campaign. Atmos Environ 34:1435-1453

Grell GA, Peckham SE, Schmitz R, McKeen SA, Frost G, Skamarock W, Eder B (2005) Fully coupled "online" chemistry within the WRF model. Atmos Environ 39:6957-6975

Hong S, Lim J (2006) The WRF single-moment 6-class microphysics scheme (WSM6). J Korean Meteorol Soc 42:129-151 
Hong SY, Noh Y, Dudhia J (2006) A new vertical diffusion package with an explicit treatment of entrainment processes. Mon Weather Rev 134:2318-2341

Jacobson MZ (2001) GATOR-GCMM: a global through urban scale air pollution and weather forecast model. 1. Model design and treatment of subgrid soil, vegetation, roads, rooftops, water, sea ice, and snow. J Geophys Res 106:5385-5402

Kaminski JW, Neary L, Struzewska J, McConnell JC, Lupu A, Jarosz J, Toyota K, Gong SL, Côté J, Liu X, Chance K, Richter A (2008) GEM-AQ, an on-line global multiscale chemical weather modelling system: model description and evaluation of gas phase chemistry processes. Atmos Chem Phys 8:3255-3281. https://doi.org/10. 5194/acp-8-3255-2008

Krol M, Houweling S, Bregman B, van den Broek M, Segers A, van Velthoven P, Peters W, Dentener F, Bergamaschi P (2005) The two-way nested global chemistry-transport zoom model TM5: algorithm and applications. Atmos Chem Phys 5:417-432

Kukkonen J, Olsson T, Schultz DM, Baklanov A, Klein T, Miranda AI, Monteiro A, Hirtl M, Tarvainen V, Boy M, Peuch V-H, Poupkou A, Kioutsioukis I, Finardi S, Sofiev M, Sokhi R, Lehtinen KEJ, Karatzas K, San José R, Astitha M, Kallos G, Schaap M, Reimer E, Jakobs H, Eben K (2012) A review of operational, regional-scale, chemical weather forecasting models in Europe. Atmos Chem Phys 12:1-87. https://doi.org/10.5194/acp-12-1-2012

Langmann B, Varghese S, Marmer E, Vignati E, Wilson J, Stier P, O'Dowd C (2008) Aerosol distribution over Europe: a model evaluation study with detailed aerosol microphysics. Atmos Chem Phys $8: 1591-1607$

Matthias V (2008) The aerosol distribution in Europe derived with the Community Multiscale Air Quality (CMAQ) model: comparison to near surface in situ and sunphotometer measurements. Atmos Chem Phys 8:5077-5097. https://doi.org/10.5194/acp-8-5077-2008

Menut L, Bessagnet B, Khvorostyanov D, Beekmann M, Blond N et al (2014) CHIMERE 2013: a model for regional atmospheric composition modelling. Geoscientific Model Development. Copernicus Publications 6(4):981-1028

Mindell J, Joffe M (2004) Predicted health impacts of urban air quality management. J Epidemiol Community Health 58:103-113

Mlawer EJ, Taubman SJ, Brown PD, Iacono MJ, Clough SA (1997) Radiative transfer for inhomogeneous atmospheres: RRTM, a validated correlated-k model for the longwave. J Geophys Res 102: 16663-16682

Olivier JGJ, van Aardenne JA, Dentener FJ, Pagliari V, Ganzeveld LN, Peters JAHW (2005) Recent trends in global greenhouse gas emissions: regional trends 1970-2000 and spatial distribution of key sources in 2000. Environ Sci 2(2-3):81-99. https://doi.org/10. 1080/15693430500400345

Saide PE, Carmichael GR, Spak SN, Gallardo L, Osses AE, MenaCarrasco MA, Pagowski M (2012) Forecasting urban PM10 and PM2.5 pollution episodes in very stable nocturnal conditions and complex terrain using WRF-Chem CO tracer model. Atmos Environ 45(2011):2769-2780

Schaap M, Sauter F, Timmermans R, Roemer M, Velders G, Beck J, Builtjes P (2008) The LOTOS-EUROS model: description, validation and latest developments. Int J Environ Pollut 32:270-290

Schell B, Ackermann IJ, Hass H, Binkowski FS, Ebel A (2001) Modeling the formation of secondary organic aerosol within a comprehensive air quality model system. J Geophys Res 106:28275-28293

Seinfeld JH, Pandis SN (1998) Atmospheric chemistry and physics from air pollution to climate change. John Wiley and Sons, Incorporated, New York

Simpson D, Benedictow A, Berge H, Bergstrom R, Emberson LD, Fagerli H, Flechard CR, Hayman GD, Gauss M, Jonson JE, Jenkin ME, Nyıri A, Richter C, Semeena VS, Tsyro T, Tuovinen J-P, Valdebenito A, Wind P (2012) The EMEP MSC-W chemical transport model - technical description. Atmos Chem Phys 12: 7825-7865. https://doi.org/10.5194/acp-12-7825-2012

Skamarock WC, Klemp JB, Dudhia J, Gill DO, Barker DM, Wang W, Powers JG (2005) A description of the advanced research WRF. Version 2. NCAR TechNote NCR/ TN-4681STR, 94 pp.

Skamarock WC, Klemp JB, Dudhia J, Gill DO, Barker DM, Duda MG, Huang XY, Wang W, and Powers JG (2008) A description of the advanced research WRF version 3. NCAR Technical Note, NCAR/TN-475thSTR, 113 pp.

Sofiev M (2000) A model for the evaluation of long-term airborne pollution transport at regional and continental scales. Atmos Environ 34:2481-2493

Spiridonov V, Curić M, Jakimovski B $(2018,2018)$ Examination of incloud sulfate chemistry using a different model initialization. Air Qual Atmos Health. https://oi.org/10.1007/s11869-018-0632-y

Stockwell WR, Middleton P, Chang JS, Tang X (1990) The second generation regional acid deposition model chemical mechanism for regional air quality modeling. J Geophys Res 95:16343-16367

Tulet P, Crassier V, Solmon F, Guedalia D, Rosset R (2003) Description of the mesoscale nonhydrostatic chemistry model and application to a transboundary pollution episode between northern France and southern England. J Geophys Res 108:4021. https://doi.org/10. 1029/2000JD000301

Zhang Y (2008) Online-coupled meteorology and chemistry models: history, current status, and outlook. Atmos Chem Phys 8:2895-2932

Zhang Y, Pan Y, Wang K, Fast JD, Grell GA (2010) WRFChemMADRID: incorporation of an aerosol module into WRFChem and its initial application to the TexAQS2000 episode. J Geophys Res 115:D18202. https://doi.org/10.1029/2009JD013443

Zhang Y, Bocquet M, Mallet V, Seigneur C, Baklanov A (2012) Realtime air quality forecasting, part I: history, techniques, and current status. Atmos Environ 60:632-655

Publisher's note Springer Nature remains neutral with regard to jurisdictional claims in published maps and institutional affiliations. 